\title{
Implementasi Kebijakan Pengalihan Kewenangan Pendidikan Menengah Dari Pemerintah Kabupaten/Kota Ke Pemerintah Provinsi (Studi Di Provinsi Sumatera Barat)
}

\author{
${ }^{1}$ Wilda Sumarsyah, ${ }^{2}$ Jendrius, ${ }^{3}$ Roni Ekha Putera \\ ${ }^{123}$ Magister Administrasi Publik,Universitas Andalas, Indonesia
}

e-mail: roniekhaputera@soc.unand.ac,.id

\begin{abstract}
Abstrak
Implementasi kebijakan adalah metode agar sebuah kebijakan dapat mencapai tujuannya. Disahkannya Undang-undang Nomor 23 Tahun 2014 tentang Pemerintah Daerah maka terjadi peralihan dalam pengelolaan yang berhubungan dengan bidang pendidikan menengah. UU Nomor 23 Tahun 2014 mengamanatkan bahwa kewenangan pengelolaan Pendidikan menengah atas yang sebelumnya dikelola oleh kabupaten/kota diserahkan ke pemerintah provinsi. Berdasarkan data dilapangan, menunjukkan indikasi belum optimalnya implementasi kebijakan pengalihan kewenangan pendidikan menengah atas ke Pemerintah Provinsi di Sumatera Barat. Tujuan penelitian untuk menjelaskan implementasi kebijakan pengalihan kewenangan pendidikan menengah atas ke Pemerintah Provinsi di Sumatera Barat. Penelitian ini menggunakan metode penelotian deskriptif kuantitatif, dengan pendekatan survei. Hasil dari penelitian ini sesuai dengan teori Edward C III bahwa implementasi kebijakan pengalihan kewenangan pendidikan menengah atas ke Pemerintah Provinsi dipengaruhi oleh empat faktor, yaitu komunikasi, sumber daya, sikap pelaksana, dan struktur birokrasi. Hasil penelitian menyatakan bahwa variabel komunikasi, sumber daya, sikap pelaksana, dan struktur birokrasi berhubungan positif dan signifikan terhadap implementasi kebijakan pengalihan kewenangan pendidikan menengah dari Pemerintah Kabupaten atau Kota ke Pemerintah Provinsi di Provinsi Sumatera Barat. Begitu juga secara parsial ditemukan bahwa variabel-variabel tersebut berhubungan positif dan signifikan terhadap implementasi kebijakan pengalihan kewenangan pendidikan menengah dari Pemerintah Kabupaten/Kota ke Pemerintah Provinsi di provinsi Sumatera Barat.
\end{abstract}

Keywords: komunikasi, sumberdaya, disposisi, struktur birokrasi, implementasi

\section{Abstract}

Policy implementation is a method for a policy to achieve its goals. The enactment of Law No. 23 of 2014 on Regional Government there is a shift in the management related to the field of secondary education. The law mandates the authority of senior high school management previously administered by the district or city to be handed over to the provincial government. Based on data in the field, there are indications that the implementation of the policy of transferring authority for senior secondary education to the Provincial Government in West Sumatra has not been optimal. The purpose of this research is to know Implementation of the Policy on Transfer of Secondary Education Authority from District or City Governments to West Sumatera Provincial Government. This study used quantitative methods, with a survei approach. The results of this study are consistent with the theory stated by Edward C. III that the policy implementation is influenced by four factors, communication, resources, executive attitudes, and bureaucratic structure. Based on the results of analysis, it can be concluded that the variables of communication, resources, executive attitudes, and bureaucratic structures positive and significant 
correlation on Implementation of the Policy on Transfer of Secondary Education Authority from District or City Governments to Provincial to West Sumatera Provincial Government. Likewise, it was found that partial variables positive and significant correlation on Implementation of the Policy on Transfer of Secondary Education Authority from District or City Governments to West Sumatera Provincial Government.

Kata Kunci : communication, resources, disposisi, bureaucratic structure, implementation

\section{PENDAHULUAN}

Disahkannya UU No 32 Tahun 2004 tentang pemerintahan daerah, sekarang telah dirubah dengan UU No 23 Tahun 2014 tentang pemerintahan daerah, bahwa penlaksanaan otonomi daerah sesuai dengan Undang-Undang Nomor 23 Tahun 2014. Berdasarkan UU No 23 Tahun 2014 tentang Pemerintahan Daerah, terdapat perubahan pembagian urusan dalam pengelolaan bidang pendidikan antara pemerintah pusat, pemerintah provinsi, dan pemerintah kabupaten atau kota ${ }^{1}$. Otonomi bidang pendidikan yang diberikan kepada Daerah memberikan keleluasaan daerah untuk menjadikan daerah unggul di bidang pendidikan. Dengan segala potensi yang dimiliki, setiap daerah menerapkan kebijakan masing-masing gunapeningkatan kualitas pendidikan ${ }^{2}$. Pendidikan menengah atas (SMA/ SMK) yang sebelumnya dijalankan oleh pemerintah kabupaten/kota, dengan adanya UU kewenangan pengelolaannya beralih ke pemerintah provinsi. Dimana tujuan dari pengalihan kewenangan tersebut agar pemerintah daerah bisa lebih fokus dalam memajukan kualitas pendidikan. Pemerintah kabupaten/kota lebih fokus menangani pendidikan dasar, Pendidikan Anak Usia Dini (PAUD) dan Pendidikan Masyarakat (Dikmas). Pemerintah kabupaten atau pemerintah kota diminta bisa mengelola pendidikan menengah atas secara optimal dan maksimal.

Kewenangan pengalihan pengelolaan pendidikan menengah atas berlaku di seluruh wilayah Indonesia. Salah satu provinsi yang melaksanakan kebijakan tersebut adalah provinsi Sumatera Barat. Pemerintah Kota Sumatera Barat khawatir perubahan tersebut tidak berdampak baik bagi pendidikan. Adanya beberapa permasalahan yang muncul sehubungan dengan peralihan kewenangan dari pengelolaan pendidikan menengah dapat juga menjadi sebuah batu sandungan tersendiri, misalnya nasib tenaga pengajar honorer yang gajinya sudah tidak dikeluarkan oleh daerah namun pemerintah provinsi belum mengganggarkan gaji mereka sebab Pemprov Sumatera Barat sekedar menganggarkan gaji untuk guru ASN. Sedangkan, gaji guru honorrer, tidak dianggarkan.

\footnotetext{
${ }^{1}$ UU No 23 Tahun 2014

${ }^{2}$ Lihat Jurnal Roni ekha putera : 2015 "Implementasi Kebijakan Otonomi Daerah Bidang Pendidikan dalam Pencapaian

“Millennium Development Goals” Ilmu Administrasi Negara, FISIP, Universitas Andalas, Padang.
} 
Gambar 1.1

Data Pendidikan Menengah di Sumatera Barat

\begin{tabular}{|c|c|c|c|c|c|c|}
\hline \multirow{2}{*}{ Nama KabatauKota } & \multicolumn{3}{|c|}{ SMA } & \multicolumn{3}{|c|}{ SMK } \\
\hline & Negeri & Swasta & Total & Negeri & Swasta & Total \\
\hline Kab. Agam & 21 & 3 & 24 & 7 & 4 & 11 \\
\hline Kab. Dhamasraya & 8 & - & 8 & 4 & - & 4 \\
\hline Kab. Kepulauan Mentawai & 6 & - & 6 & - & - & - \\
\hline Kab. Lima Puluh Kota & 9 & - & 9 & 3 & 2 & 5 \\
\hline Kab. Padang Pariaman & 15 & 6 & 21 & 2 & 10 & 12 \\
\hline Kab. Pasaman & 7 & 3 & 10 & 4 & 2 & 6 \\
\hline Kab. Pasaman Barat & 10 & 7 & 17 & 4 & 5 & 9 \\
\hline Kab. Pesisir Selatan & 21 & - & 21 & 3 & 10 & 13 \\
\hline Kab. Sijunjung & 15 & - & 15 & 3 & 2 & 5 \\
\hline Kab. Solok & 21 & 1 & 22 & 1 & 3 & 4 \\
\hline Kab. Solok Selatan & 7 & - & 7 & 5 & 2 & 7 \\
\hline Kab. Tanah Datar & 16 & 3 & 19 & 5 & 5 & 10 \\
\hline Kota Bukittingi & 6 & 5 & 11 & 2 & 11 & 13 \\
\hline Kota Padang & 17 & 36 & 53 & 10 & 32 & 42 \\
\hline Kota Padang Panjang & 3 & 4 & 7 & 2 & 3 & 5 \\
\hline Kota Pariaman & 5 & 2 & 7 & 4 & 4 & 8 \\
\hline Kota Sawahlunto & 2 & 2 & 4 & 2 & 1 & 3 \\
\hline Kota Solok & 4 & 1 & 5 & 2 & 4 & 6 \\
\hline Kota Payakumbuh & 3 & 3 & 6 & 7 & 5 & 12 \\
\hline
\end{tabular}

Sumber: Dinas Pendidikan Provinsi Sumatera Barat, 2019

Dari data yang diperoleh, sebanyak 447 unit Pendidikan jenjang SMA atau SMK yang telah diserah terimakan dari kabupaten atau kota ke provinsi Sumatera Barat. Selain unit Pendidikan tenaga pengajar dan pegawai, juga dialihkan. Setidaknya 2.800 guru honor yang sebelumnya menerima SK dari bupati atau walikota, beralih menjadi tanggungan pemerintah provinsi sejak 2017. Sayangnya, hingga kini para guru tersebut masih menerima gaji berdasarkan jam berdiri per bulan, bukan jam berdiri per minggu. Sehingga, dalam sebulan, para guru hanya menerima gaji untuk ukuran satu minggu mengajar.

Tugas berat pemerintah provinsi Sumatera Barat adalah memberikan standar pelayanan pendidikan yang berkualitas, atau minimal sama dengan pelayanan yang diberikan oleh kabupaten/kota sebelumnya. Pemberian layanan pendidikan ini tentu tidak mudah karena ruang lingkup Pendidikan SMA atau SMK yang ditangani oleh pemerintah provinsi menjadi lebih luas. Implikasi yang langsung dirasakan yaitu bertambahnya beban keuangan pemerintah provinsi dengan adanya pelimpahan kewenangan SMA atau SMK peningkatan anggaran dalam bidang pendidikan juga disebabkan pelimpahan aset-aset SMA atau SMK menjadi beban provinsi (ada 447 Pendidikan). Aset-aset seperti bangunan Pendidikan yang dilimpahkan tidak semuanya dalam kondisi yang baik. Oleh karenanya, pemeliharaan dan rehabilitasi dari gedung-gedung Pendidikan tersebut dibebankan kepada pemerintah provinsi. Tidak hanya itu, pembangunan unit Pendidikan baru beserta sarana dan prasarananya juga menjadi tanggung jawab provinsi. Contoh, di Sumatera Barat, terdapat 9 kabupaten/kota yang sudah menyelenggarakan pendidikan gratis SMA/SMK.

Ketika dialihkan ke provinsi, dikawatirkan kebijakan tersebut tidak dilanjutkan karena kemampuan anggaran yang membebani provinsi juga bertambah. Pengambilalihan pengelolaan pendidikan menengah oleh provinsi sangat berdampak pada Pendidikan yang terletak di pelosok daerah. 
Masih banyaknya Pendidikan menengah yang terletak di pelosok daerah yang keterbatasan tenaga pendidik dan sarana dan prasarana. Sepeerti, guru PNS yang ada di sekolah-sekolah dipelosok jumlah gurunya di bawah 50\% dibandingkan dengan jumlah guru honor. Sementara dari segi sarana prasarana hampir semua sekolah tak memiliki sarana penunjang pembelajaran yang lengkap, khususnya prasarana komputer.

Dari segi pegawasan adanya kesulitan pengawasan dan pembinaan, termasuk mengadakan koordinasi. Seperti diketahui koordinasi untuk setingkat kota dan kabupaten saja sulit apalagi untuk tingkat provinsi. Ini disebabkan karena wilayah pemerintahan provinsi lebih luas dari wilayah kabupaten/kota. Terkadang untuk masalah administrasi, Dinas Pendidikan Kabupaten/Kota sering keteteran. Dari segi sumber daya manusia ditangani provinsi, baik kenaikan pangkat, mutasi tenaga kependidikan, dan sebagainya. Bagi mereka yang mempunyai keinginan ditempatkan pada zona nyaman di daerahnya selama bekerja tentunya juga merasa terancam.

Berdasarkan Teori Implementasi Kebijakan Publik George Edward III menjelaskan bahwa pelaksanaan kebijakan adalah metode yang krusial karena seberapa efektifnya suatu kebijakan kalau tidak dipersiapkan dan diagendakan dengan baik maka apa yang menjadi tujuan kebijakan publik tidak akan terwujud $^{3}$. Sehingga, untuk mendapatkan tujuan kebijakan, perumusan kebijakan dan implementasi harus dipersiapkan dan diagendakan dengan baik. Berdasarkan teori kebijakan publik, problem yang terkait implementasi kebijakan dapat ditelusuri dengan pendekatan teori implementasi kebijakan publik. Menurut ( Goerge Edwards III) ada faktor yang mempengaruhi implementasi kebijakan yaitu komunikasi, sumber daya, disposisi, struktur birokrasi ${ }^{4}$.

Dilihat dari model Edwards III, permasalahan-permasalahan yang timbul terkait pengalihan kewenangan pendidikan menengah atas karena masih banyaknya Pendidikan menengah atas yang terletak di pelosok daerah yang keterbatasan tenaga pendidik, sarana dan prasaran dapat dikategorikan dalam faktor sumber daya. Selain itu, nasib tenaga pengajar honorer yang gajinya sudah tidak dikeluarkan oleh daerah juga dapat digolongkan dalam faktor sumber daya. Aset-aset seperti bangunan Pendidikan yang dilimpahkan tidak semuanya dalam kondisi yang baik juga dapat digolongkan dalam faktor sumber daya. Dari segi pegawasan adanya kesulitan pengawasan dan pembinaan, termasuk mengadakan koordinasi dapat digolongkan sebagai faktor struktur birokrasi.

Dari sejumlah permasalahan yang melatar belakangi penulis menyimpulkan bahwa faktor sumber daya dan struktur birokrasi merupakan faktor utama yang menghambat implementasi kebijakan pengalihan kewenangan pendidikan menengah dari Pemerintah Kabupaten atau Kota ke Pemerintah Provinsi Di Sumatera Barat. Faktor-faktor lain yang disebutkan Edwards III seperti komunikasi dan disposisi juga diduga memberikan kontribusi sebagai hambatan dalam implementasi implementasi kebijakan pengalihan kewenangan pendidikan menengah atas dari Pemerintah Kabupaten atau Kota ke Pemerintah Provinsi Di Sumatera Barat., sehingga hal ini perlu diteliti kebenarannya.

Berdasarkan latar belakang, penulis membahas masalah ini ke dalam sebuah judul penelitian yakni implementasi kebijakan pengalihan kewenangan pendidikan menengah dari Pemerintah Kabupaten/Kota ke Pemerintah Provinsi Di Sumatera Barat. Tujuan penelitian ini untuk Menjelaskan implementasi kebijakan pengalihan kewenangan pendidikan menengah dari Pemerintah Kabupaten atau Kota ke Pemerintah Provinsi Di Sumatera Barat. Manfaat penelitian dapat menjadi tambahan referensi atau acuan bagi mahasiswa maupun pihak lain dan sebagai bahan penelitian selanjutnya untuk mengembangkan dan menyempurnakan penelitian ini.

\footnotetext{
${ }^{3}$ Edwards, George C, III. 1980. Implementing Public Policy. Washington Dc : Texas A \& M University . Congretional Quarterly Press

${ }^{4}$ Edwards III. Op. Cit. Hal 10
} 


\section{METODE}

Jenis penelitian ini adalah deskriptif kuantitatif yaitu menggambarkan tentang suatu genjala atau fenomena tertentu ${ }^{5}$. Penelitian ini mengguanakan metode survey yaitu suatu upaya untuk mengumpulkan informasi dari responden dengan mengunakan kuesioner ${ }^{6}$. Populasi dalam penelitian ini adalah SMA dan SMK di Sumatera Barat yang berjumlah 447 unit Pendidikan. Sampel yang digunakan dalam penelitian ini didapat dengan teknik pengambilan sampel probability sampling (metode pengambilan sampel secara acak) dengan jenis Multistages Random Sampling. Dengan jumlah populasi sebanyak 447 Pendidikan menengah atas dengan tingkat kekeliruan yang digunakan adalah 5\%, maka jumlah sampel yang diteliti adalah 81 unit Pendidikan. Dalam pengumpulan data dikembangkan instrumen penelitian berupa kuesioner, wawancara, format observasi dan daftar isian. Kuesioner berisikan pertanyaan-pertanyaan untuk menjaring informasi atau data yang diperlukan dalam penelitian yang ditujukan kepada responden yang terkait dalam penelitian ini. Pada prinsipnya, pendekatan kuantitatif dilakukan pada penelitian inferensial (dalam rangka pengujian hipotesis) dan mengandalkan kesimpulan hasilnya pada suatu probabilitas/peluang.

\section{HASIL DAN PEMBAHASAN}

\subsection{Hubungan Variabel Komunikasi dengan Implementasi Kebijakan pengalihan kewenangan Pendidikan Menengah Atas dari Kabupaten/Kota ke Pemerintahan Provinsi di Sumatera Barat}

Komunikasi memiliki peranan yang sangat kursial dalam penyampaian suatu kebijakan, sebab kebijakan yang akan disampaikan harus di pahami dengan baik oleh pelaksananya. Dengan begitu kebijakan tersebut dapat dikomunikasikan dan disiarkan dengan jelas, akurat dan konsisten serta tidak memicu konflik. Hasil penelitian menunjukkan hubungan yang kuat dan berpola positif bermakna antara variabel komunikasi dengan impelementasi pengalihan kewenangan pendidikan menengah atas ke provinsi. Dilihat dari uji menggunakan Spearman Rank yang dihasilkan yakni 0,611** hal ini menunjukkan ada hubungan yang sangat kuat dengan arah yang positif artinya semakin tinggi intensitas komunikasi semakin tinggi pula efektivitas implementasi Pengalihan Kewenangan Pendidikan Menangah Atas ke Provinsi di Sumatera Barat dan sebaliknya semakin rendah intensitas komunikasi semakin rendah pula efektivitas implementasi Pengalihan Kewenangan Pendidikan Menangah Atas ke Provinsi di Sumatera Barat. Hal ini sesuai dengan teori yang dikemukakan oleh Edward III dalam Agustino yang menyatakan bahwa penyaluran komunikasi yang baik akan dapat menghasilkan suatu implementasi yang baik pula.

Komunikasi pada konteks penelitian ini digunakan agar pemangku kebijakan pengalihan kewenangan pendidikan menengah atas ke provinsi di Sumatera Barat dapat berjalan dengan efektif. Komunikasi ini dilakukan oleh Dinas Pendidikan Sumatera Barat. Untuk mengkomunikasikan kebijakan ini kepada Pendidikan menengah atas maka dalam penyampaiannnya harus benar dan tepat agar Pendidikan dapat memahami kebijakan pengalihan kewenangan pendidikan menengah atas ke provinsi.

Dari hasil penelitian, Proses komunikasi dan sosialiasi kebijakan telah mengantar Dinas Pendidikan Provinsi Sumatera Barat dapat mengimplementasikan kebijakan tentang pengalihan kewenangan Pendidikan Menengah Atas dari Kabupaten/Kota ke Pemerintahan Provinsi. Informasi yang dimengerti

\footnotetext{
${ }^{5}$ Sugiyono. 2013. Metode Penelitian Kuantitatif Kualitatif dan R\&D. Bandung: Alfabeta

${ }^{6}$ Isna, A Dan Warto. 2013. Analisis Data Kuantitatif : Panduan Praktis UntukPenelititan Sosial : Dilengkapi Dengan Analisis Regresi Nominal Dan Ordinal. Purwokerto : Stain Press
} 
para pengambil keputusan terlihat dengan adanya tiga parameter yang digunakan yaitu sosialisasi/transmisi, kejelasan dan konsistensi. Langkah-langkahyang dilaksanakan oleh Dinas Pendidikan Provinsi Sumatera Barat terkait pengalihan kewenangan Pendidikan Menengah Atas melalui dua cara yaitu secara langsung dan tidak langsung. Secara langsung komunikasi dilakukan dengan melakukan sosialisasi dan rapat koordinasi, sedangkan komunikasi tidak langsung dilakukan melalui surat menyurat. Hasil yang dicapai dari proses komunikasi terlihat dari terlaksananya koordinasi intensif antara pemerintah provinsi dan kabupaten/kota, termasuk berkaitan dengan dokumen atau data yang merujuk pada proses sosialisasi seperti daftar penerimaan ATK, Surat Keputusan (SK). Dengan demikian proses komunikasi Pengalihan Kewenangan Pendidikan Menangah Atas ke Provinsi di Sumatera Barat sudah terlaksana dengan sesuai waktu yang telah ditentukan, pengalihan SMA/SMK tidak hanya dilakukan antar pelaksana kebijakan tetapi juga oleh kepala Pendidikan dan pihak yang dikenai secara langsung oleh kebijakan yang telah ditetapkan.

Sebagaimana penelitian dari Dennis Abel Timotius Panjaitan, Budi Gutami, Suhartoyo, (2017) dan Abdullah Wahid (2014) menjelaskan bahwa keberhasilan implementasi kebijakan masyaratkan agar implementor mengetahui apa yang harus dilakukan. Dengan demikian, untuk lebih meningkatkan efektivitas implementasi pengalihan kewenangan pendidikan menangah atas ke provinsi di Sumatera Barat hendaknya peraturan mengenai kebijakan pemerintah dalam implementasi pengalihan kewenangan pendidikan menangah atas ke provinsi di Sumatera Barat dapat dikomuniasikan dan disosialisasikan dengan baik sehingga setiap peraturan dan prosedur pada pelaksanaan dapat dipahami dan diikuti oleh seluruh lembaga Pendidikan.

\subsection{Hubungan Variabel Sumber Daya dengan Implementasi Kebijakan pengalihan kewenangan Pendidikan Menengah Atas dari Kabupaten/Kota ke Pemerintahan Provinsi di Sumatera Barat}

Implementasi kebijakan cenderung menjadi tidak efektif, meskipun perintah-perintah implementasi ditransmisikan secara cermat, jelas dan konsisten, apabila memiliki kekurangan sumbersumber yang diperlukan oleh pelaksana untuk menjalankan kebijakan ${ }^{7}$. Hasil penelitian menunjukkan hubungan yang kuat dan berpola positif bermakna antara variabel Sumber Daya dengan Implementasi pengalihan kewenangan pendidikan menangah atas ke provinsi. Dilihat dari uji menggunakan Spearman Rank yang dihasilkan yakni $0,696 * *$ hal ini menunjukkan ada hubungan yang sangat kuat dengan arah yang positif artinya semakin tinggi intensitas sumber daya semakin tinggi pula efektivitas implementasi Pengalihan Kewenangan Pendidikan Menangah Atas ke Provinsi di Sumatera Barat dan sebaliknya semakin rendah intensitas sumber daya semakin rendah pula efektivitas implementasi Pengalihan Kewenangan Pendidikan Menangah Atas ke Provinsi di Sumatera Barat.

Implementasi kebijakan tidak akan berhasil jika tidak adanya dukungan dari sumber daya manusia yang cukup baik, baik dari aspek kualitas dan kuantitasnya ${ }^{8}$. Kualitas sumber daya manusia berhubungan dengan keterampilan, konstribusi, profesionalitas, dan kompetensi di bidangnya, sedangkan kuantitas berhubungan dengan jumlah sumber daya manusia apakah sudah cukup untuk mencakupi seluruh kelompok sasaran. Sumber daya manusia (staff) yang dimaksud dalam pelaksanaan kebijakan pengalihan kewenangan pendidikan menangah atas ke provinsi adalah guru yang merupakan sebagai seorang pendidik, pembimbing, dan mediator pada proses pembelajaran. Sumber daya nonmanusia mencakup dana yang akseptable, ketersedian sarana dan prasana. Menurut Edward III, Sumber daya non manusia merupakan faktor penting dalam implementasi kebijakan. Pemangku kebijakan dapat memiliki staf yang memadai, mengerti apa yang harus dilakukannya, dan memiliki kewenangan untuk melaksanakan tugasnya, tapi tanpa adanya sarana dan prasarana maka implementasi kebijakan tidak akan efektif.

\footnotetext{
${ }^{7}$ Nugroho, Dr. Riant. 2014. Kebijakan Publik di Negara-Negara Berkembang. Yogyakarta: Pustaka Pelajar

${ }^{8}$ Widodo. 2010. Implementasi kebijakan. Yogyakarta : Andi Offset
} 
Dari hasil penelitian, Sumber daya dalam penelitian ini dinilai sudah mencukupi dalam implementasi kebijakan ini. Sumber daya manusia secara kuantitas sudah mencukupi. Sedang secara kualitas diketahui bahwa semua responden memiliki tingkat pendidikan yang tinggi, mempunyai kapabilitas dan kompetensi yang baik, baik berkaitan dengan keterampilan, sikap dan profesionalitas di bidang keahliannya. Sedangkan kuantitas berhubungan dengan ketersedian jumlah staf/karyawan yang melaksanakan kebijakan pengalihan pendidikan menengah atas. Hal ini menunjukkan bahwa responden memiliki kemampuan yang tinggi dalam implementasi kebijakan pengalihan kewenenangan pendidikan menengah atas ke provins di Sumatera Barat.

Sebagaimana Dennis Abel Timotius Panjaitan, Budi Gutami, Suhartoyo, (2017) dan Abdullah Wahid (2014), dan menjelaskan bahwa titik sentral dari Jalan tidaknya implementasi kebijakan terletak pada sumber daya. Walaupun isi kebijakan sudah dikomunikasikan secara jelas dan konsisten, tetapi jika pemangku kebijakn kekurangan sumber daya untuk mengimplementasikan kebijakan, implementasi tidak akan berjalan efektif. Ini menadi bukti nyata, bahwa sumber daya manusia, sumber daya nonmanusia (anggaran maupun sarana dan prasarana) dapat mempengaruhi efektivitas implementasi kebijakan.

\subsection{Hubungan Variabel Disposisi dengan Implementasi Kebijakan pengalihan kewenangan Pendidikan Menengah Atas dari Kabupaten/Kota ke Pemerintahan Provinsi di Sumatera Barat}

Disposisi/sikap pelaksana akan menyebabkan halangan yang nyata terhadap implementasi kebijakan bila personel yang ada tidak meimplementasikan kebijakan yang diinginkan. Oleh karena itu, pemangku kebijakan mesti orang-orang yang memiliki konstribusi pada kebijakan yang telah ditetapkan. Hasil penelitian menunjukkan hubungan yang sedang dan berpola positif bermakna pula antara Disposisi dengan Impelementasi kebijakan pengalihan kewenangan pendidikan menengah atas ke provinsi. Hasil penelitian hubungan yang bermakna antara sikap pelaksana dengan impelementasi pengalihan kewenangan pendidikan menengah atas ke provinsi. Dilihat dari uji menggunakan Spearman Rank yang dihasilkan yakni $0,459^{* *}$. Hal ini menunjukkan ada hubungan yang cukup kuat dengan arah yang positif artinya semakin tinggi intensitas disposisi semakin tinggi pula efektivitas implementasi Pengalihan Kewenangan Pendidikan Menangah Atas ke Provinsi di Sumatera Barat dan sebaliknya semakin rendah intensitas disposisi semakin rendah pula efektivitas implementasi Pengalihan Kewenangan Pendidikan Menangah Atas ke Provinsi di Sumatera Barat. Disposisi/sikap pelaksana adalah tanggung jawab pelaksana terhadap kebijakan. Disposisi/sikap pelasana merupakan faktor yang penting dalam pendekatan kebijakan publik. Jika pelaksanaan kebijakan ingin efektif, maka para pemangku kebijakan tidak hanya mengetahui apa yang akan dilakukan tetapi juga memiliki kapabilitas untuk melaksanakan kebijakan, sehingga dalam praktiknya tidak bias.

Dari hasil peneliti, sikap pelaksanaan dalam implementasi pengalihan kewenangan pendidikan menengah atas ke provinsi di Sumatera Barat ditanggapi dengan baik. Dalam konteks implementasi kebijakan pengalihan kewenangan pendidikan menengah di Sumatera Barat, karakteristik pelaksana mengacu pada karakteristik Dinas Pendidikan Sumatera Barat sebagai lembaga pelaksana teknis pengelolaan pendidikan menengah di Sumatera Barat. Sebagai pengelola teknis pendidikan jenjang SMA/SMK di Sumatera Barat, Dinas Pendidikan memprioritaskan pelayanan kepada masyarakat. Hal ini mengacu secara kecenderungan penerimaan dan sikap para pegawai dinas pendidikan terhadap kebijakan yang ada cenderung mendukung implementasi pengalihan pendidikan menengah atas di Sumatera Barat.

Sebagaimana Dennis Abel Timotius Panjaitan, Budi Gutami, Suhartoyo, (2017) dan Abdullah Wahid (2014), dan menjelaskan bahwa disposisi adalah watak dan karakteristik yang dimiliki oleh implementor, seperti komitmen, kejujuran, sifat demokratis. Jika pelaksana memiliki disposisi yang baik, maka kebijakan berjalan dengan baik sesuai yang diinginkan oleh pembuat kebijakan. Saat pelaksana memiliki sikap yang berbeda dengan pembuat kebijakan, maka proses implementasi kebijakan juga tidak efektif. 


\subsection{Hubungan Variabel Stuktur Birokrasi dengan Implementasi Kebijakan pengalihan kewenangan Pendidikan Menengah Atas dari Kabupaten/Kota ke Pemerintahan Provinsi di Sumatera Barat}

Struktur birokrasi adalah faktor yang penting terhadap keberhasilan implementasi. Ketika strukur birokrasi tidak mendukung terhadap implementasi suatu kebijakan, maka akan menyebabkan ketidak berhasilan dan menghalangi jalanya implementasi kebijakan. Hasil penelitian menunjukkan hubungan yang sedang dan berpola positif bermakna pula antara struktur birokrasi dengan impelementasi kebijakan pengalihan kewenangan pendidikan menengah atas ke provinsi. Dilihat dari uji menggunakan Spearman Rank yang dihasilkan yakni $0,449 * *$. Hal ini menunjukkan ada hubungan yang cukup kuat dengan arah yang positif artinya semakin tinggi intensitas struktur birokrasi semakin tinggi pula efektivitas implementasi Pengalihan Kewenangan Sekolah Menangah Atas ke Provinsi di Sumatera Barat dan sebaliknya semakin rendah intensitas disposisi semakin rendah pula efektivitas implementasi Pengalihan Kewenangan Sekolah Menangah Atas ke Provinsi di Sumatera Barat.

Dari hasil penelitian, implementasi kebijakan pengalihan kewenangan pendidikan menengah atas ke provinsi di Sumatera Barat dapat dilihat dari pembagian tugas. Dalam struktur organisasi sekolah, tersedia pembagian kerja pada masing-masing staff. Sekolah mempunyai job description untuk setiap jabatan dimana setiap pelaksana bertanggung jawab atas pekerjaannya. Pelaksanaan kebijakan ini pada sekolah menengah atas di Sumatera Barat telah sesuai dalam peran dan tugas serta koordinasi antar intansi pelaksana kebijakan yang telah ditetapkan oleh pemerintah pusat. Pembagian peran dimaksudkan untuk mempermudah pelaksanaan kebijakan ini. Sejalan dengan hasil penelitian dari Dennis Abel Timotius Panjaitan, Budi Gutami, Suhartoyo, (2017) dan Abdullah Wahid (2014), yang menjelaskan bahwa struktur birokrasi turut memberikan andil terhadap implementasi kebijakan.

\section{KESIMPULAN}

Hasil penelitian untuk variabel sumber daya menunjukkan hubungan yang kuat dan berpola positif bermakna antara variabel Sumber Daya dengan Implementasi pengalihan kewenangan pendidikan menangah atas ke provinsi. Dilihat dari uji menggunakan Spearman Rank yang dihasilkan yakni 0,696**. Sumber daya dalam penelitian ini dinilai sudah mencukupi dalam implementasi kebijakan ini. Sumber daya manusia secara kuantitas sudah mencukupi. Seperti sumber daya manusia secara kuantitas sudah mencukupi, sumber daya fasilitas yang meliputi sarana prasarana dirasa cukup, karena setiap sekolah sudah ada ruang pustaka, ruang labor, ruang kelas yang sangat erat kaitannya dengan kegiatan pendidikan, sumber daya anggaran dinilai masih kurang bahwa anggaran daerah yang dimiliki Pemerintah Provinsi Sumatera Barat masih kurang sepenuhnya untuk mendanai pengelolaan Sekolah Menengah Atas tersebut di seluruh kabupaten/kota.

Hasil penelitian hubungan yang bermakna antara sikap pelaksana dengan impelementasi pengalihan kewenangan pendidikan menengah atas ke provinsi. Dilihat dari uji menggunakan Spearman Rank yang dihasilkan yakni $0,459^{* *}$. Sikap pelaksanaan dalam implementasi pengalihan kewenangan pendidikan menengah atas ke provinsi di Sumatera Barat ditanggapi dengan baik. Hal ini menunjukkan bahwa secara kecenderungan penerimaan dan sikap para pegawai dinas pendidikan terhadap kebijakan yang ada cenderung mendukung proses implementasi pengelolaan pendidikan menengah di Sumatera Barat.

Hasil penelitian untuk variabel struktur birokrasi menunjukkan hubungan yang sedang dan berpola positif bermakna pula antara struktur birokrasi dengan impelementasi kebijakan pengalihan kewenangan pendidikan menengah atas ke provinsi. Dilihat dari uji menggunakan Spearman Rank yang dihasilkan yakni $0,449 * *$. Struktur birokrasi di Sumatera Barat dalam implementasi ini sudah berjalan dengan cukup baik. 


\section{SARAN}

Berdasarkan hasil penelitian untuk variabel komunikasi menunjukkan hubungan yang kuat dan berpola positif bermakna antara variabel komunikasi dengan impelementasi pengalihan kewenangan pendidikan menengah atas ke provinsi. Dilihat dari uji menggunakan Spearman Rank yang dihasilkan yakni $0,611 * *$. Proses komunikasi dan sosialiasi kebijakan telah mengantar Dinas Pendidikan Provinsi Sumatera Barat dapat mengimplementasikan kebijakan tentang pengalihan kewenangan Sekolah Menengah Atas dari Kabupaten/Kota ke Pemerintahan Provinsi. proses komunikasi Pengalihan Kewenangan Sekolah Menangah Atas ke Provinsi di Sumatera Barat sudah terlaksana dengan sesuai waktu yang telah ditentukan, pengalihan Sekolah Menengah Atas tidak hanya dilakukan antar pelaksana kebijakan tetapi juga oleh kepala sekolah dan pihak yang dikenai secara langsung oleh kebijakan yang telah ditetapkan

\section{DAFTAR PUSTAKA}

[1] Abdullah, Wahid. 2014. Implementasi Kebijakan Bantuan Dana Biaya Operasional Sekolah (BOS) Di Kota Palu. Universitas Tabulako

[2] Dennis Abel Timotius Panjaitan, Budi Gutami, Suhartoyo, 2017. Analisis Yuridis Terhadap Peralihan Bidang Pendidikan Menengah DariPemerintah KabupatenatauKota Kepada Pemerintah Provinsi Sebagai iImplementasi Undang-undangNomor 23 Tahun2014 Tentang Pemerintahan Daerah. Ilmu Hukum, Fakultas Hukum, Universitas Diponegoro. Volume 6

[3] Edwards, George C, III. 1980. Implementing Public Policy. Washington Dc : Texas A \& M University . Congretional Quarterly Press

[4] Isna, A Dan Warto. 2013. Analisis Data Kuantitatif : Panduan Praktis UntukPenelititan Sosial : Dilengkapi Dengan Analisis Regresi Nominal Dan Ordinal. Purwokerto : Stain Press

[5] Nugroho, Riant. 2014. Kebijakan Publik di Negara-Negara Berkembang. Yogyakarta: Pustaka Pelajar.

[6] Putera, Roniekha, 2015, Junal "Implementasi Kebijakan Otonomi Daerah Bidang Pendidikan dalam Pencapaian "Millennium Development Goals". Ilmu Administrasi Negara, FISIP Universitas Andalas Padang. https:atauatauejournal.unisba.ac.idatauindex.phpataumimbaratauarticleatauviewatau1322

[7] Sugiyono. 2013. Metode Penelitian Kuantitatif Kualitatif dan R\&D. Bandung: Alfabeta

[8] Undang-Undang No. 20 Tahun 2014 tentang otonomi daerah

[9] Widodo. 2010. Implementasi kebijakan. Yogyakarta : Andi Offset 